\title{
Inhalasi Aromaterapi Lavender (Lavendula angustifolia) dan Neroli (Citrus aurantium) dengan nyeri post parttum
}

\author{
Nurul Azizah \\ nurulazizah@umsida.ac.id, +6281553902006, Prodi Kebidanan, Fakultas Ilmu \\ Kesehatan, Universitas Muhammadiyah Sidoarjo
}

\begin{abstract}
Abstrak. Setelah persalinan ibu akan merasakan nyeri hampir seluruh tubuh, luka jahitan, nyeri perut karena kontraksi rahim, tulang rusuk dan punggung terasa nyeri dan tidak nyaman karena jarum epidural, hal ini akan berlangsung beberapa hari dan akan diatasi dengan obat pereda nyeri. Aromaterapi lavender dan Neroli dipercaya dapat mengurangi rasa nyeri, Tujuan penelitian mengetahui efektivitas inhalasi aromaterapi lavender dengan neroli terhadap penurunan nyeri post partum. Metode penelitian quasi eksperimental, jumlah responden 60 ibu post partum dengan kriteria bersalin normal, post partum hari 1-2, dibagi menjadi 2 kelompok yang diberikan inhalasi aromaterapi lavender dan neroli, analisis univariabel menggunakan mean dan standar deviasi, analisis bivariabel menggunakan uji statistik independent sample $T$ test. Hasil penelitian menunjukkan rerata skor nyeri mengalami penurunan pada kelompok intervensi inhalasi aromaterapi lavender sebanyak 2.36 0.15 , pada kelompok inhalasi aromaterapi neroli menunjukkan rerata penurunan skor nyeri sebanyak 3,03 $\pm 0,067$ dengan nilai signifikan $\mathrm{P}<0,002$ menunjukkan terdapat hubungan yang bermakna. Aromaterapi lavender dan neroli efektiv menurunkan intensitas nyeri post partum, pada kelompok dengan intervensi inhalasi aromaterapi neroli menunjukkan skor penurunan nyeri lebih tinggi dibandingkan kelompok intervensi inhalasi aromaterapi lavender.
\end{abstract}

Kata kunci : Post Partum, Lavender, Neroli, Nyeri

\section{Post-Partum Pain Relief: Aromatherapy Effectiveness of Lavender (Lavendula angustifolia) and Neroli (Citrus aurantium)}

Abstract. Maternal labor induces almost full body pain, such as abdominal pain due to uterine contractions and back discomfort due to epidural needles, these vexing experience will last several days and can be relieved by painkiller prescriptions. This study compares the effectiveness of pain-relieving aromatherapy, namely by using lavender (Lavendula angustifolia) and neroli (Citrus aurantium) to decrease post-labor pain. Using the quasiexperimental method, which makes 60 respondents inhale aromatherapies within $1-2$ days of the normal and post-partum periods. Data were analyzed statistically through mean, standard deviation, and independent $t$-test. Results showed a mean reduction in pain scores using lavender inhalations with a score of $2.36 \pm 0.15$, whereas neroli inhalations show the score $3.03 \pm 0.067$, with a p-value of $<0.002$ indicating a significant relationship. In summary, neroli has a greater effectivity than lavender in reducing post partum pain.

Keywords: Post Partum, Lavender, Neroli, Pain 


\section{Pendahuluan}

Kontraksi uterus pasca persalinan akan menimbulkan nyeri merupakan hal yang fisiologis, kontraksi yang bagus dapat menghindari resiko kompilkasi persalinan yakni perdaraan post partum. Mayoritas wanita (95\%) post partum akan mengalami nyeri perineum dalam 24 jam setelah proses persalinan, dan $100 \%$ wanita yang mengalami nyeri jika terjadi robeken perineum setelah persalinan (Macanthur el al, 2004). Nyeri tersebut akan berkurang pada dalam beberapa hari, pada hari ke 7 post partum $60 \%$ terjadi pada perineum intac, dan $91 \%$ rasa nyeri masih terjadi pada ibu post partum dengan robekan perineum (Macanthur el al, 2004).

Nyeri post partum besifat fisiologi serta berlangsung beberapa hari setelah proses persalinan, hal tersebut dapat menjadikan ibu trauma bagi ibu jika nyeri tersebut tidak tertangani dengan baik dan benar, sebab itu penanganan nyeri pada ibu post partum sangat penting agar tidak menjadi pengalaman yang buruk bagi ibu bersalin. umumnya nyeri pasca proses persalinan di atasi dengan terapi farmakologi yakni pemberian obat analgesic, namun tetapi sering menimbulkan efek samping yang buruk bagi ibu, seperti munculnya alergi terhadap obat, bahkan ibu bersalin dengan komplikasi penyakit tertentu sehingga menjadikan kontraindikasi jika dikonsumsi oleh ibu. (Snyder \& Lindquist 2002).

Penanganan nyeri post partum dapat menggunakan terapi non farmakologi diataranya dengan aromaterapi. Aromaterapi dipercaya sebgai alternative penghilang rasa nyeri, embuat perasaan menjadi nyaman sehingga dapat mengatasi gangguan emosional, dan mampu menimbulkan sensasi menenangkan sehingga stress dapat berkurang (Laila, 2011). Aromaterapi dinilai dapat menimbulkan rasa nyaman melalui berbagai indikator, seperti munculnya respon rasa fight or flight, adanya rasa nyaman yang timbul dapat meningkatkan konsentrasi dan kinerja, pikiran lebih tenang, serta membuat jiwa terasa menjadi lebih nyaman (Price, dan Wilson, 2005).

Inhalasi aromaterapi dapat dilakukan dengan meneteskan minyak essensial pada kapas/tissue, telapak tangan, serta dengan steam (laura, 2012). Terdapat perbedaan dari beberapa penelitian tentang kosentrasi pengencerandan lama pemberian aromaterapi inhalasi untuk mengurangi nyeri. Olapour et al., (2012) meneliti tentang pengaruh aroma terapi lavender terhadap nyeri pasca operasi sesar. Pada penelitian tersebut menggunakan minyak essensial $10 \%$ yang dihirup selama 5 menit dengan jarak $10 \mathrm{~cm}$ dari pasien. Sedangkan Ozgoli et al., (2012) dalam penelitiannya menggunakan 0,2 ml minyak essensial papermint dalam 2 ml normal salin untuk menurunkan nyeri persalinan, intervensi diulang setiap 30 menit. Namzi et al., 2014 menggunakan $8 \mathrm{ml}$ minyak essensial citrus aurantium yang di encerkan 
dengan 100ml air, kemudian masingmasing responden diberikan larutan minyak essensial yang telah diencerkan sebanyak $4 \mathrm{ml}$ yang ditempatkan pada alat penguap, intervensi ini diulang tiap 30 menit, Kavaini (2014) dalam penelitiannya menggunakan $0,1 \mathrm{ml}$ air yang dihirup dengan mengguanakan tissue . intensitas nyeri diukur setelah 30 menit dan 60 menit pemberian aromaterapi, hasilnya kelompok yang diberikan aromaterapi mengalami nyeri persalian lebih rendah dibandingkan dengan kelompok kontrol.

Aromaterapi lavender dapat mempengaruhi sistem limbik di otak yang merupakan pusat emosi, serta dapat menghasilkan endorfin dan enkefalin yang dapat menurunkan rasa nyeri, serotonin mempunyai peran menghilangkan ketegangan otot yang dapat menimbulkan stres serta kecemasan (Perez, 2003). Neroli dipercaya sebagai aromaterapi yang dapat mengurangi peradangan dan stres, dengan merangsang sirkulasi yang dapat meningkatkan mood (yanik, 2016).

Beberapa aromaterapi juga dapat digunakan sebagai terapi yakni, lavender, kemangi, kayumanis, neroli, kenanga, melati, cendana, cengkih, mawar. Saat ini penanganan nyeri yang sering digunakan sebagai terapi komplementer adalah minyak essensial atau aromaterapi lavender, lavender dipercaya mempunyai sifat antikonvulsan, anxiolytic, antidepresi serta bersifat menenangkan (Gentz, 2001). Penelitian ini bertujuan untuk mengetahui perbandingan inhalasi aromaterapi lavender (Lavendula Augustfolia) dan neroli (Citrus Aurantinum) terhadap penurunan nyeri post patum

\section{Metode}

Desain penelitian menggunakan quasi experiment non equivalent control group. Dengan membandingkan skor nyeri sebelum dan sesudah diberikan intervensi, analisis univariabel menggunakan mean dan standart deviasi, analisis bivariabel menggunakan uji statistik independent sample $\mathrm{T}$ test. Total responden penelitin ini sebanyak 60 ibu post partum, dibagi menjadi 2 kelompok, terdiri dari 30 ibu post partum dengan intervensi inhalasi aromaterapi neroli, serta $30 \mathrm{ibu}$ post partum diberikan intervensi inhalasi aromaterapi lavender. Dengan kriteria sampel ibu post partum dengan riwayat persalinan normal pada hari ke 1-2. Pengumpulan data dilakukan dengan cara melakukan pengukuran tingkat nyeri pada post partum sebelum dan setelah di berikan intervensi inhalasi aromaterapi lavender dan neroli, intrumen penelitian menggunakan skala nyeri NRS (Numeric Rating Scale), kemudian data dikumpulkan dan di analisis serta membandingkan selisih nilai penurunan skor nyeri pretest dan post test pada kedua kelompok. 


\section{Hasil Penelitian}

Tabel 1. Distribusi Frekuensi Responden

\begin{tabular}{llllll}
\hline \multirow{2}{*}{ Characteristics } & Group 1 & \multicolumn{3}{c}{ Group 2 } & \multirow{2}{*}{ p-value } \\
\cline { 2 - 5 } & $\mathrm{N}$ & $\%$ & $\mathrm{~N}$ & $\%$ & \\
\hline Umur & & & & & \\
$20-35$ tahun & 25 & $83.33 \%$ & 27 & $90 \%$ & 0.760 \\
$>35$ ytahun & 5 & $16.67 \%$ & 3 & $10 \%$ & \\
& & & & & \\
Paritas & 13 & $43.33 \%$ & 16 & $53.33 \%$ & 0.768 \\
$\begin{array}{l}\text { Primigravida } \\
\text { Multigravida }\end{array}$ & 17 & $56.67 \%$ & 14 & $46.67 \%$ & \\
Note: Group 1 is administered with lavender (Lavendula angustifolia), while group 2 is administered with neroli (Citrus aurantium)
\end{tabular}

Berdasarkan tabel 1 menunjukkan komparabilitas pada subyek penelitian adalah homogen atau sebanding diantara variabel penelitian yakni usia dan paritas, hasil skor nyeri didapatkan $\mathrm{P}>0,05$ yakni tidak ada perbedaan yang bermakna sebelum dilakukan intervensi yakni distribusi data secara merata sebelum dilakukan penelitian.

Tabel 2. Skor Nyeri pre dan post di berikan intervensi aromaterapi

\begin{tabular}{|c|c|c|c|c|c|}
\hline \multirow{2}{*}{ Treatment } & \multirow{2}{*}{\multicolumn{2}{|c|}{ Aromatherapy Types }} & \multicolumn{2}{|l|}{ t-test } & \multirow{2}{*}{ Sig. } \\
\hline & & & Mean & $\mathbf{N}$ & \\
\hline \multirow[t]{2}{*}{ Pre-test } & $\begin{array}{l}\text { Lavender } \\
\text { angustifolia) }\end{array}$ & (Lavendula & 6.03 & 30 & 0.000 \\
\hline & Neroli (Citrus & antium) & 7.00 & 30 & 0.000 \\
\hline \multirow[t]{2}{*}{ Pos-ttest } & $\begin{array}{l}\text { Lavender } \\
\text { angustifolia) }\end{array}$ & (Lavendula & 3.67 & 30 & 0.001 \\
\hline & Neroli (Citrus & antium) & 3.97 & 30 & 0.002 \\
\hline \multirow[t]{2}{*}{ Difference } & $\begin{array}{l}\text { Lavender } \\
\text { angustifolia) }\end{array}$ & (Lavendula & 2.87 & 30 & 0.002 \\
\hline & Neroli (Citrus & antium) & 3.03 & 30 & 0.003 \\
\hline
\end{tabular}

Dari tebel 2 diketahui bahwa kelompok dengan inhalasi aromaterapi lavender (Lavendula Angustifolia) sebelum di berikan intervensi menunjukkan rerata skor nyeri post partum 6.03, setelah diberikan intervensi terdapat penurunan intensitas nyeri post partum dengan rerata
3,67. Sedangkan pada kelompok dengan inhalasi aromaterapi neroli (Citrus Aurantium) sebelum diberikan intervensi mempunyai rerata skor nyeri sebesar 7.00, dan setelah diberikan intervensi terdapat penurunan intensitas skor nyeri post partum sebesar 3,97. 
Table 3. Aromatherapy Inhalation Difference

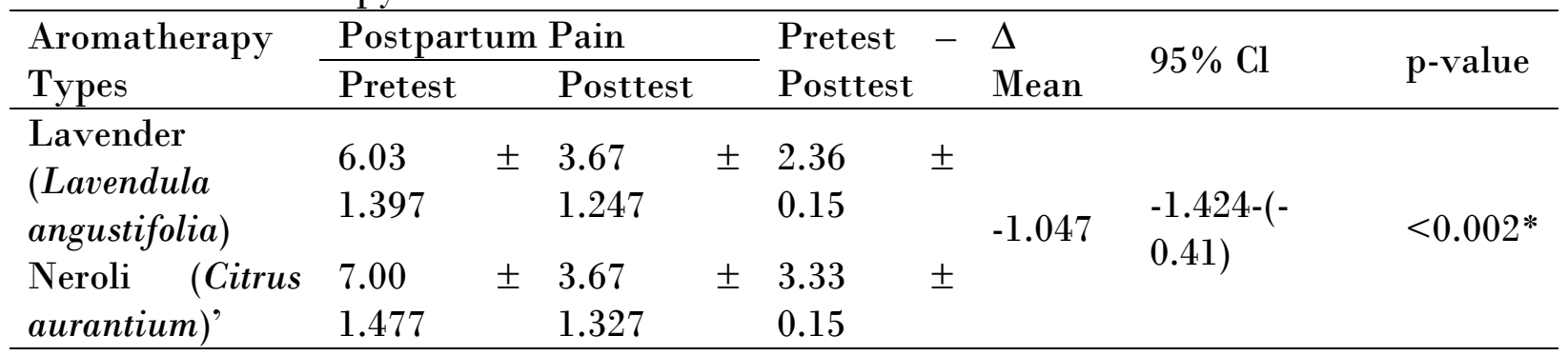

Note: ${ }^{*}$ denotes t-test result

Dari tabel 3 didapatkan bahwa pada kelompok dengan intervensi inhalasi aromaterapi lavender menunjukkan rerata penurunan skor intensitas nyeri post partum sebesar $2.36 \pm 0.15$, sedangkan pada kelompok dengan intervensi inhalasi aromaterapi neroli (Citrus Aurantium) menunjukkan penurunan skor intensitas nyeri sebesar $3.33 \pm 0.15$. Dari hasil analisis uji Independent Sample T-Test didapatkan nilai $\mathrm{P}<0,002$ dengan 95\% C.I. -1,424-(0,410). Hal ini menunjukkan bahwa penurunan skor nyeri post partum setelah pemberian aromaterapi inhalasi Lavender (Lavendula Angustifolia) dan neroli (Citrus Aurantium) bermakna secara statistik maupun klinik.

\section{Pembahasan}

Penelitian ini menganalisis secara statistik komparabilitas variabel-variabel penelitian. Proporsi sampel penelitian ini menunjukkan tidak ada perbedaan yang bermakna $(\mathrm{P}>0,05)$. Artinya dari usia dan paritas terdistribusi secara homogeny/merata dan sebanding. Berdasarkan hasil tersebut variabel yang merupakan subyek penelitian ini diperkirakan dapat mempengaruhi intensitas nyeri, tidak terdapat perbedaan diantara kelompok, sehingga kemungkinan bias yang disebabkan variable luar tersebut dapat dihindari.

Berdasarkan hasil penelitian yang didapatkan rerata skor nyeri kelompok intervensi inhalasi aromaterapi lavender (Lavendula Angustifolia) dan neroli (Citrus Aurantium) sebelum diberikan intervensi tidak ada perbedaan yang bermakna $(\mathrm{P}<0,05)$. Hasil ini menunjukkan bahwa sebelum diberikan intervensi, skor intensitas nyeri pada kedua kelompok tidak berbeda.

1. Inhalasi aromaterapi lavender (Lavendula Angustifolia) terhadap penurunan nyeri postpartum

Hasil analisis didapatkan bahwa inhalasi aromaterapi lavender (Lavendula Angustifolia) menunjukkan adanya pengaruh intensitas penurunan skor nyeri post partum, dengan rerata sebesar 2,36 $\pm 0,15$ dan nilai $\mathbf{P}<0,002$. Hal tersebut menunjukkan adanya hubungan yang bermakna dalam penurunan intensitas nyeri sebelum dan sesudah diberikan intervensi. penurunan intensitas skor nyeri post partum menunjukkan hasil yang signifikan sehingga hipotesis dapat diterima. 
Nyeri post partum adalah hal yang fisiologis, nyeri terebut muncul akibat adanya proses penghantaran nyeri melalui sel saraf aferen (neuron sensori) dan serabut konektor (interneuron) serta sel saraf aferen (neuron motorik) yang dihantarkan ke otak, akibatnya secara otomatis tubuh mempresepsikan menjadi suatu rasa nyeri. nyeri merupakan respon sensori subjektif serta emosional serta rasa tidak menyenangkan, hal tersebut terjadi akibat adanya kerusakan jaringan secara actual atau potensial, atau dapat juga menggambarkan kondisi terjadinya kerusakan (Lyndon, 2013).

Aromaterapi lavender (Lavendula Angustifolia) juga mempunyai manfaat mengatasi insomnia, serta dapat memperbaiki suasana hati, dengan memberikan efek relaksasi. Menurut pendapat Sharma (2009) aromaterapi lavender yang juga bersifat analgesik yakni dapat meredakan nyeri termasuk juga meringankan nyeri otot dan juga kepala, aromaterapi lavender juga bersifat antibakterial, antiinflamasi, antifungal, antiseptik, dan juga penenang. Oleh sebab itu aromaterapi lavender (Lavendula Angustifolia) dapat dijadikan salah satu alternatif terapi sebagai terapi non farmakologis dalam penanganan nyeri postpartum, selain dapat mempengaruhi kondisi fisik juga dapat berpengaruh terhadap kondisi psikologis ibu menjadi lebih baik.

Menurut Dochterman (2004), Aromaterapi dapat diberikan melalui beberapa cara atau metode, dianataranya, melalui pijat, inhalasi, salep topikal, serta kompres (panas\&dingin). Aromaterapi dapat menimbulkan efek relaksasi serta dapat digunakan sebagai terapi pengobatan untuk mengurangi nyeri (Burns2007).
Selain untuk mengurangi rasa nyeri aromaterapi lavender juga dipercaya mempunyai sifat antiseptik. Menurut kurniati (2004) juga menjelaskan bahwa manfaat aromaterapi didapatkan melalui molekul serta partikel lavender saat dihirup kemudian masuk melewati hidung, diterima oleh reseptor saraf yang teridentifikasi sebagai signal yang baik, kemudian diinterpretasikan sebagai aroma yang menyenangkan, aroma tersebut akan mempengaruhi sensori sistem limbik yang merupakan pusat emosi seseorang, akibatnya saraf dan pembuluh darah dapat merubah perasaan menjadi relaks sehingga rasa nyaman yang ditimbulkan dan nyeri dapat berkurang. Selain itu aaat aromaterapi dihirup zat aktif yang terdapat dalam aromaterapi dapat merangsang hipotalamus (kelenjar hipofise) untuk mengeluarkan endorphin hormon, yang mana telah diketahui bahwa hormon endorphin dapat menimbulkan rasa tenang, relaks, serta bahagia (Smith, Collins, Crowther et al, 2011).

\section{Aromaterapi Neroli (Citrus Aurantium) terhadap penurunan nyeri ibu postpartum}

Hasil analisis didapatkan yakni inhalasi aromaterapi neroli (Citrus Aurantium) menunjukkan adanya pengaruh penurunan intensitas skor nyeri pada post partum, dengan rerata sebesar $3.33 \pm 0.15$ dan nilai $P$ $<0,002$. Hal ini berarti intervensi inhalasi aromaterapi neroli sebelum dan sesudah diberikan intervensi terdapat penurunan intensitas skor nyeri yang bermakna sehingga hipotesis diterima.

Aromaterapi saat dihirup akan merangsang pelepasan neurotransmiter otak sehingga dapat menimbulkan relaksasi akibarnya 
nyeri juga dapat berkurang (Burn et al., 1999). Aroma wangi yang keluarkan aromaterapi dapat menstimulasi thalamus mengeluarkan enkefalin dengan endorphin yang mana keduanya dapat berfungsi menurukan rasa nyeri secara alami (Vakilian et al., 2011). Minyak esensial dapat meningkatkan aktivitas serabut saraf aferen yang berfungsi untuk mengurangi persepsi nyeri melalui cara menutup gate atau gerbang nyeri (Telfer, 1997). Aromaterapi neroli (Citrus Aurantium) memiliki efek antiseptik dan anti depresi, antispasmodic, sedative ringan, serta dapat meningkatkan gairah seksual (Leite et al., 2008 dalam Namazi et al., 2014). Menurut Namzi selain memberikan efek keharuman, aromaterapi juga dapat memberikan keuntungan baik digunakan melalui metode inhalasi maupun dioleskan ke kulit. Implementasi aromaterapi melalui inhalasi juga dapat mempengaruhi perubahan psikologis manusia, aromaterapi neroli (Citrus Aurantium) jika di hirup akan meningkatkan gelombang alfa pada otak sehingga dapat menciptakan perasaan rileks (Namazi et al., 2014).

Pada penelitian Sarrou et al. (2013) menyebutkan pada Citrus Aurantium terdapat kandungan linalool (29,14\%) yang merupakan komponen terbesar pada minyak esensial neroli (Citrus Aurantium), kemudian $\beta$-pinene $(19,08 \%)$, limonene $(12,04 \%)$, trans- $\beta$-ocimene $(6,06 \%)$ dan $\mathrm{E}$ farnesol (5,14\%). Pada minyak esesnsial Citrus Aurantium terdapat senyawa limonene berfungsi untuk mengontrol cyclooxygenase I dan II, serta mencegah aktivitas prostaglandin, dapat digunakan untuk menurunkan rasa nyeri (Cherargi, 2010 dalam Namazi et al., 2014). Linalool dapat berfungsi sebagai anti cemas/relaksasi (Sarrou et al. 2013).

Penelitian menunjukkan hasil bahwa dari kelompok dengan intervensi inhalasi aromaterapi lavender (Lavendula Angustifolia) dan neroli (Citrus Aurantium) dapat mengurangi intensitas skor nyeri post partum secara signifikan. Terdapat perbedan rerata skor penurunan nyeri post partum yang menunjukkan kelompok inhalasi aromaterapi neroli (Citrus Aurantium) menunjukkan skor penurunan nyeri lebih tinggi dibandingkan dengan aromaterapi lavender.

\section{Simpulan}

Terdapat pengaruh yang bermakna pada kelompok yang diberikan intervensi inhalasi aromaterapi lavender dan aromaterapi neroli terhadap intensitas nyeri post partum. kelompok yang diberikan intervensi inhalasi aromaterapi neroli menunjukkan skor penurunan intensitas nyeri lebih tinggi dibandingkan kelompok aromaterapi lavender.

\section{Daftar Pustaka}

Anggraeni P., Setyawati H., and Wijayanti K. The Effectivity of Abdominal Lifting and Counter Pressure for Postpartum Pains within Stage I Active Phase in Tidar General Hospital Magelang. Universitas Muhammadiyah Magelang. 2010.

Argi B.V and Nuraeni S. The Effect of Lavender Aromatherapy to Postoperative Pain Intensity in Dustira Cimahi Hospital, Jurnal Keperawatan Soedirman., Vol.8 No.2, 2013, 120-126.

Balcin M.L. The safety issue in aromatherapy. Aromatherapy science; a guide for healthcare 
professionals. London:

Pharmaceutica Press. 2006.

Bobak I.M., Lowdermilk D.L., and Jensen M.D. Maternity Nursing. Fourth edition. Jakarta: EGC. 2005.

Burns E., Blamey C., Ersser S.J., Lioyd A. J., and Barnetson L. The Use of Aromatherapy in Intrapartum Midwifery Practice: An evaluative study. Oxford Brookes University, England Report no.7. 1999.

Burns E., Zobbi V., Panzeri D., Oskrochi R., and Regalia A.. Aromatherapy in childbirth: a pilot randomised controlled trial, Int. J. Obstet. Gynaecol., Vol. 114, 2007, 838-844.

Dochterman J. Nursing intervention Classification (NIC). Fourth edition. USA: Mosby. 2004.

Gentz B. Alternative Therapies for the Management of Pain In labor and Delivery, Clin. Ob \& Gynecol., Vol. 44, 2001, 704-732.

Laila, N.N. Menstruation Smart Book, Yogyakarta: Buku Biru. 2011

Laura W. Protocol for the Use of Aromatherapy in Labour Care. Royal Berkshire: NHS Foundation Trust. 2012.

Leite M., Fassin J., Baziloni F., Almeida R., Rita M., and Leite R. Behavioral effects of essential oil of Citrus aurantium $L$. inhalation in rats, $J$. Pharmacognosy, Vol. 18, 2008, 661666.

Lyndon, S. Clinical Nursing and Practice Guidebook. Tangerang Selatan: Karisma. 2013.

Magfuroh A. Factors Affecting Labor Pain within First Stage Active Phase in Kabupaten Tangerang General Hospital's Delivery Room. Thesis. Universitas Islam Negeri Syarif Hidayatullah. 2012.

Manuaba I.B.G., I.A. Chandranita
Manuaba, and I.B.G Fajar Manuaba. Introduction to Obstetrics. Jakarta: EGC. 2007

Namazi M., Akbari S., Mojab F., Telebic A., Majd H., and Jannesaria S. Effects of Citrus Aurantium (Bitter Orange) on the Severity of FirstStage Labor Pain. Iranian Journal of Pharmaceutical Research, Vol. 13 No. 3, 2014, 1011-1018.

Olapour A., Behaeen K., Akhondzadeh R., Soltani F., Razavi F.S., Bekhradi R. The Effect of Inhalation of Aromatherapy Blend containing Lavender Essential Oil on Cesarean Postoperative Pain, Anesth Pain Med, Vol.3 No.1, 2013, 203-207.

Perez, C. Clinical Aromatherapy Part 1: An introduction into nursing practice. Clin J. Oncol Nurs., Vol.7 No.5, 2003, 595-596

Prawirohardjo, S. Midwifery Sciences. Jakarta: Yayasan Bina Pustaka Sarwono Prawirohardjo. 2008.

Price, S.A., and Wilson, L.M., Pathophysiology: Clinical Concepts of Disease Processes. Jakarta: EGC. 2005

Sarrou E., Chatzopoulou P., Theriou K.D., and Therios I. Volatile Constituents and Antioxidant Activity of Peel, Flowers, and Leaf Oils of Citrus Aurantinum L. Growing in Greece, Molecules Vol.18, 2013, 10639-10647

Sharma S., Menia V., Bedi J., and Dogra S. Labor Analgesia: An Unmet Right of Laboring Women in India. Journal of South Asian Federation Obstetrics and Gynaecology, Vol.5 No.1, 2013, 26-32.

Smith C.A, and Bare, B.G. Aromatherapy for Pain Management in Labour. Cocrane Database of Systematic Review, Issue 7 No.CD009215. 2011

Snyder M., and Lindquist R. 
Jurnal Ilmiah Kesehatan Vol XIII, No II, September 2020 ISSN 1978-3167, E-ISSN 2580-135X

Complementary Alternative

Therapies in Nursing. Fourth

Edition. New York: Springer

Publising Company. 2002

Telfer F. M. Relief of Pain in Labour. In:

Sweet B. R. Tiran D. Mayes

Midwifery: A text book for midwives, 12th Ed., Balliere Tindall, London. 1997

Vakilian K., Karamat A., Mousavi A., Shariati M., Ajami M. and Atarha M. The effect of Lavender essence via inhalation method on labor pain. J. Shahrekord University Med. Sci., Vol. 14, 2011, 34-40.

Walsh L.V. Midwifery: Community-based Care during the Childbearing Year. Second Edition, Jakarta: EGC, 2008.

Yanik, (2016), Benefits of Neroli Essential oil.

https://www.spadibali.com/manfaatdari-minyak-essential-neroli Accessed 10 April 2020 